Arhe XVIII, 35/2021

UDK $165.6 / .8: 001$

DOI https://doi.org/10.19090/arhe.2021.35.279-312

Originalni naučni rad

Original Scientific Article

\author{
KONSTANTINOS G. PAPAGEORGIOU ${ }^{1}$ \\ University of Athens, Department of Philosophy, Greece \\ DEMETRIOS E. LEKKAS ${ }^{2}$ \\ Hellenic Open University, Studies in Greek Civilization, Greece
}

\title{
EPISTEM $\bar{E}$ VS SCIENCE
}

\begin{abstract}
Is "science" the corresponding concept of its Greek progenitor, epistēmē? Traditionally, they were thought of as identical concepts. They are not, in more than one way, and the reader is called to evaluate them not based on their chronological order but on the specific systemic characteristics presented here. The crucial difference between the epistemonic (from epistēmē) method and the scientific method will also be presented. One of the main differences that will be discussed is related to logic, both as a concept and as a theory. What the authors present here is by no means a synthesis of past ideas; we do acknowledge that some similar ideas might have appeared in the past but never in the form presented here or within the system proposed in what follows. This work is not about who did not say whatever we propose or who might have some similar thoughts within some irrelevant context. All ideas here stem from original work done solely by us and the ensuing system is unique and of utmost important being also an external critique - the only truly external critique - to the institution of modern science and to the grave inconsistencies "scientists" cannot (for whatever reason) notice in it anymore.
\end{abstract}

Keywords: Scientific method, epistemonic method, theoretical witchcraft, logic

\section{INTRODUCTION}

Little has happened since the 2014 Greek conference announcement "Epistēme vs Scientia". Because of the ensuing passivity, it is time for an updated version of that discussion: the incompatibility of the concepts

\footnotetext{
${ }^{1}$ Author's e-mail address: cconstantinoss@gmail.com

2 Author's e-mail address: ja-dim@ @otmail.com
} 
epistème and science. The tension between the two concepts should be one of the most important insights of our era. The reluctance of the scientific community to even consider such a total failure of our most cherished and valuable knowledge system, science, can only be considered as confirmation of its weakness. This reluctance is not followed by any counterarguments, save for one: "but look at how good the results of science are, look at technology!" Let us disregard how close the implied relationship between science and technology truly is. The argument is based on the end-result, on the output of a process and not on any sound systemic criteria, as has always been the standard practice in science, but never in classically formulated epistēme which evaluates and judges based on the criteria of consistency, completeness, theoretical productivity and elegance. Here we will attempt to shed some more light upon the different criteria each knowledge system has.

\section{THE BACKGROUND}

Decades of research led D. E. Lekkas to present in 1995 his doctoral dissertation in Greek: The Mathematical Theory of Music, in which he introduced a whole branch back to mathematics, giving it the potential to come out as one of the most important contributions of the millennium in Mathematics. It does have inconceivable implications for both mathematics and physics. Music (as a typical theory) is the cover theory for all periodic phenomena, showing, for example, the use of complex analysis for periodic phenomena as being redundant and offbeat. What happened next? Again, not much. Lekkas himself attempted to publish some articles in various international peer-reviewed journals; however, they would not even review the manuscripts as they could not summon "peers", based on the tough reality that no-one seemed to be able to comprehend the information as physicists did not know music and musicians did not know physics; no one would accept to assumed such responsibility! Feeling like a victim of a universal prevailing specialisation, he never attempted to publish anything again in any major peer-reviewed journal, living in obscurity since then, watching highly celebrated scientists making one mistake after another (and being awarded various prestigious prizes for them). Recently, the authors 
have attempted to provide a platform for these insights through a new peerreviewed journal we have created on our own: Epistēmēs Metron Logos.

Here are some factors within the current scientific realm that explain the reluctance to accommodate the formal mathematical theory of music:

- Epistemology viewed as history. It could be said that History of Science and Epistemology are different fields; however, the fact is that epistemologists will not take the responsibility of creating a normative theory of knowledge (as medical doctors do in medicine), preferring to just passively record the history of the field.

- The current paradigm of expertise. The notion of the contributory expert generalist (Papageorgiou \& Lekkas, 2020) is not only alien to science but also harmful for its authoritarian structure; however, expert specialists are in no position to evaluate such far-reaching breakthroughs.

- References as a default way to support any argument. They are of the utmost importance in order to support anything; this backfires in two ways: anyone can support almost anything based on literature; but also, if literature in some areas does not exist, then new theories are out of the question.

In effect, three such instances occur where no prior bibliography exists:

1. the formal theory of music (as was first presented by the Pythagoreans, only to be removed from mathematics by the vindictive Aristoxenus and his followers),

2. contributory expert generalists (confused with polymaths who are generalists but not contributory ones),

3. science vs. epistēme (considered, until now, conceptually identical).

Here, we will focus not only on the tension between science and epistēmē, but also on some key implications for logic. What is needed is for the reader to use their basic intuition and understanding of the most fundamental notions of science, as well as of key relationships between the most elementary of ideas regarding logic. If something more is needed for a 
basic understanding, at least one of us has failed miserably: the author or the reader or... both.

\section{THE EMERGENCE OF THE PROGENITOR OF SCIENCE: EPISTEM $\bar{E}$}

The special circumstances occurring in Athens could well be the driving force behind the flourishing of dialectics. Classical Athens was neither a specimen of "typical Greece" (indeed: an exception of the rule), nor did other Greeks particularly like Athenians; after all, it was fellow Greeks who put an end to Athenian dominance (and existence even). However, these "special circumstances" endured for an amazing century, a phenomenon nowhere to be found before or afterwards in such a lengthy duration.

These special circumstances basically included the co-existence of markedly different cultures and currents of thought that could only coexist either under extreme suppression and violence or under dialectics. Let us not now get entangled into a historiographical study of the vast differences of the population of classical Athens (others have made that sort of research), but let us examine, in a systemic way, the equilibrium mechanisms of such compositions. When different entities mix, there are elements in common, elements not in common and elements that are incompatible. So, under this given situation, how do thesis, antithesis and synthesis play together so that dialectics and logic can be set up? There are three possibilities:

1. Reject all differences, keep all similarities (set intersection): the most minimalistic type of composition.

2. Accept everything and put them under one authority (set union): the most maximalistic type of composition; it requires some sort of resolution to deal with incompatibilities.

3. Combinations of the former two cases.

The rarest case, the second one, occurred in Classic Athens for a whole golden century. This changed the world. In a world scene consisting of city-states and empires, Athens was not just an exception, but the timely exception. A key for all this to succeed was the language itself: the venerated Attic Greek with the following unique combination of elements: 
1. It features two (2) negative particles (giving the possibility to logical quadrupoles to evolve);

2. it differentiates syntactically its "definitive" mood from its subjunctive mood, thus sharply differentiating between planned or anticipated and observable events;

3. it features two syntactical kinds of infinitives (telic or infinitives of intent and specific or infinitives of content)

4. sensory, cognitive verbs of emotion are connected with attributive or complementary participles, thus expressing state of being and not state of acting.

Were these and other similar linguistic characteristics the cause for the development of epistēmē? Yes and no; in actuality, it was more like a synergy. Language gained some characteristics because of the said circumstances, peculiar only to Athens, and then abstract thought grew easier, which itself helped the language to further evolve and so on and so forth, each side helping the other: the language boosted epistēmē and epistēmē helped towards perfecting language. Language, alone, was the necessary condition for the development of epistēmē, but not the sufficient one; it became sufficient as soon as abstract thought started to produce its first fruits, which then helped language to evolve and the language-epistēmē spiral to keep evolving.

Only on this linguistic structural substrate, consisting of sensory and cognitive verbs going with categorical participles, revealing what you are and not what you do, abstract thought emerges, almost inevitably from a point on. It observes and it evaluates phenomena, it does not simply record; it is not an accounting system like Latin; (not) surprisingly, when Latium was a city-state, the language was also equipped with two negation particles; but when it started becoming an empire, it got rid of the second negation becoming dipolar.

Indicative mood vs "definitive" mood. All these special characteristics that expressed the dynamics of the Greek Golden Era characteristics that the Golden Era only magnified - did not express what was "common public conception and perception" in the Roman Empire, a fact that Roman scholars knew all too well when they were transplanting or 
"adapting" the terminology of the Greek grammar translating literally wordby-word (calque). They understood that the specific grammatical choices of the Classical Era could not be used in their literal sense in the Roman Empire and they had to change them using loose synonyms.

Maybe the best example is that of the basic linguistic mode, the Latin modus indicativus.

When Latin scholars were accurately translating word-for-word (calque) all of the Greek grammatical terms in order to create Latin grammar (e.g. article, preposition, verb, adverb, conjunction, nominative, genitive, accusative, subjunctive, participle), they very characteristically broke the calque and changed some terminology. Why would they do that unless the literalness of the translation suddenly betrayed the meaning that the particular grammatical feature exhibited in classical Latin?

Why is there a difference between declension and conjugation when they are both called clisis in Greek? Why does conjugation literally render

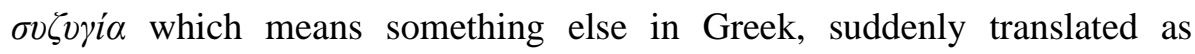
syzygy? what happened when they came across a specific grammatical mood, enclisis horistikē? This mood may be quite accurately translated as modus definitivus. Why did they prefer to call it modus indicativus instead? Was that just an "innocent liberty"? Or could it be that they saw through the fact that the famous Rule of Law of the Holy Roman Empire was much better served by a grammatical mood, which was fixed upon the "objective reality" that can be indicated - i.e.: pointed out - by our fingers (indicare, cf. index finger)? The indicative would certainly not be a mood that points at the real world, recording observations and certifying facts; it would be one that allows the subject, i.e. us, to create the conception of the world freely based on how we choose to define things and then discuss the state of affairs standing by their conceptual definitions, comparing and contrasting them but, in any case, assuming intrinsic personal responsibility regarding how we have defined what. The Greek language and thought had been stuck with this very pattern, adhering to the model of abstraction and application that is idiomatic to philosophy and theoretical mathematics. Modus indicativus might have served the Roman Empire well; but is it the proper vehicle for epistēmē? 
Jumping some millennia forward, it is only in such a context that a system such as Logical Empiricism could have emerged and flourished. If one needs to anchor "abstract" theories onto the real world, then modus indicativus is the perfect vehicle. When scientists considered verifying theories via observations, quite possibly they thought: "oh well, why not? Let's give it a try!", or even (somewhere in Vienna)...

"Na ja, warum nicht? Laß es uns versuchen!"

Reality vs truth. It is interesting to note how even in Latin or in English "truth" (or veritas ${ }^{3}$ ) is terminologically differentiated from "reality"; Greek $\dot{\alpha} \lambda \dot{\eta} \theta \varepsilon i \alpha$, alètheia, meaning to not miss anything, i.e. to take everything into account, stands even further aside truth ${ }^{4}$. Reality refers to the world out there, to Dinge an sich. Truth is, or should be, totally abstract, with no connection at all to the world. It is in the way of mathematics, meaning nothing and open to any interpretation; counting things does not affect numbers themselves. Science is based on reality and on experiments that verify the reality of theories; epistemme is based on truth. Whereas there exists an exact term for truthfully speaking in public, verdict, science insists

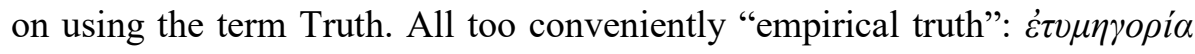
(etymegoriā), has exactly the same meaning and etymology with the word verdict: to speak truthfully in public. But what is the meaning of truth - at least that of logical truth?

\footnotetext{
${ }^{3}$ from verus, "true", and that has indeed the same root as, say, German Wahrheit; that comes from Middle High German wār, wēere, from Old High German wār, wäri; both of them, then, come from PIE root *were-os (trusted, trustworthy), conceivably ultimately related to proto-root *war meaning to rise up

${ }^{4}$ English truth, one among them, together with abstract noun and verb trust, comes from another Germanic abstract noun *treuwitho, from Proto-Germanic treuwaz "having or characterized by good faith", related to German treu, from PIE *drew-o-; further on, this is a suffixed form of the PIE root *deru-, "be firm, solid, steadfast", related to Latin adjective durus $=$ hard.
} 
The meaning of truth emerges when someone asks a by-passer about its antonyms. One would easily identify two: falsities (fallacies, errors) and falsehoods (lies). Therefore, our abstract idea of truth should express both these meanings, hence we should have "necessarily true" (expressing the realist mode) and possibly true (expressing sincerity).

Whatever " $T$ " (truth) we have in abstract logic, it literally means nothing and, moreover, it doesn't have to express truth with these two meanings, of reality and of sincerity. Therefore, we do have the right to try both types of truth (necessary and possible) in our logical system and see what we get. Can we have a consistent logical system with both meanings of truth?

The possible outcomes are four:

1. Sincerity works

2. Reality works

3. Both work

4. Neither works

In the special case that both meanings work, we can claim that our standard, our theory about logical truth is interpretable in these two ways (while a priori it doesn't mean any of these two or anything at all) and therefore we have a good model of truth which is applicable to the world. Logic does not have reality as a starting point; it merely has theoretical standards that may be suitable for anything, nothing or something. In the case that a theory suits nothing from reality (because we have been unsuccessful when trying to assign various meanings to some theory), then we have two options: to treat it as a meaningless mental game, or to try and correct it - especially if it is something important (such as logic is to do dialectics). So, to cut a long story short, can logic's Truth accommodate reality and/or sincerity?

If we input reality, then our system shifts to a "definitional" hindmost foremost, violating the direction of logical inference from a cause A (a model) towards an effect B (reality). In that case we will be unable to deal in empiricism (science) based on epistēmē (theory). So, let us try out sincerity instead. 
Sincerity is related to intentions and to expectations. Therefore, a logical Truth expressing psychological modes would concern psychology and maybe the neurosciences in general, but not science.

So, when we develop a logic system based on necessary truth and potential truth, these two kinds of truth mean nothing at all and the meaning will vary only afterwards, when we apply them to the real world in anything that we would like to do.

Theory will not and cannot tell what is true regarding the world; It may only tell us whether what we choose to refer to as "true" can actually be true. For example, a certain a posteriori choice of what is true, when assigned back to the theory (logic), may produce contradictions within the logical system; so, that cannot constitute a valid meaning for truth. On the other hand, if we perform a number of logical tests and they are successful, then that kind of meaning is acceptable. To cut a long story short, what we do is that we visualize a concept or version or shade of "truth" here (as we do about different ideas and concepts in different sets of circumstances, as e.g. within arithmetic, geometry, analysis, calculus, complex systems etc.), check and test it against a particular axiomatic / theorematic theory at a time, appraise how the attempted matching performs by itself and as compared and contrasted to other rival matches. Then, if we do find the particular match satisfactory, we keep this theoretical ambit in order to express our "reality" through it. This will last until such time as we catch it critically misperforming, or until another theory shows up outperforming our current one, or until we get very of it and decide to dispose of it for any reason at all or even for none whatsoever. Usually, though, we keep a match that tests "non-unacceptable and "good enough" until a "better" one hits us, so we deem that it is time to move on to it; or until someone else spots and points out a fatal flaw, which we had failed to spot on our own.

In practice, for instance, we can choose to call truth whatever a politician says. Will that lead to a consistent system for truth? No, because such a system (based on what politicians say) will be inconsistent. And if the reader finds this example far-fetched, remember that many people do actually define truth based on what their religion says - and then they have to explain the inconsistencies; in this spirit, all sorts of excuses are provided (some people call such excuses hypocrisy, but who are we to tell?). This 
effort to define truth based on some system of observations, reality or texts reminds us of the concept of "saving the phenomena", i.e. how to accommodate incompatible new observations with older theories. Then, in order to use an external system as the basis for what truth is, we will soon have to either change the system or dismiss the truth in the way that we have described it. So, what is true and what is truth?

This part cannot be stressed enough: theory does not predetermine what truth is; it is the way in which we assign our observations to theory that the concerned observations may be said to express truth. In still other words: the axiomatic system tells how to deal with identities of True and False, not what truth per se is. When the theory gets to be interpreted, we try to load on it or some version of what we may wish to mean by truth (e.g. a statement that is formally proved, or a statement that is apocalyptically believed, or a statement that does not lie, i.e. says things in the way that the speaker trusts that they actually are, or a statement that is supported as factually correct, and all that in a necessary sense, or alternatively all that in a potential sense); and right then and there we see "what happens", in the sense of checking and deeming whether the semantic content that we have tentatively assigned to "truth" or "ventured to suspend from it" does or does not work in the frame of the axiomatic / theorematic ambitus employed from its own blissful non-committal abstraction. If it does, then we are set: we infer that the particular version and shade and degree of "truth" meant or desired or aspired by us is usable in the realm of this theory, and we are free to adopt this meaning; if it does not, then our shot at an interpretation of truth has failed and we have to look for something else: either shift towards another attempted semantic content and focus and try the theory again, or keep it and seek or concoct another theory, resetting and restarting the same process over again. And then and only then, in stages of application, we may "have" and "employ" a specific "literal" sense of what truth is, but right then and there and by us and for as long as we all agree: only within the field of application and in the specific instance under evaluation (within and by the ambit of this theory and its isomorphs and homomorphs and extensions).

Conclusively, it is not the theory that will tell us what truth means; it is we ourselves who will check and decide whether our attempted meaning for truth works within the theory employed so that we are or are not free to 
use "Theory A" as expressing and accommodating "Truth X"; will it be truthfulness? Will it be transcendental creed? Will it be our inner inspiration? Will it be observational fact? Will it be an interpretative and/or organizational model for building and treating our "reliable data"? Will it be a high cultural value? And, will the previous shade be applicable necessarily? Sufficiently? To an "adequate weighted statistical significance" (considering such and such utilities and/or penalties or costs and/or benefits? We shall appraise, decide and take on or drop. It all comes down to an ultimate choice and consensus of accepting as true what we accept as true provided, at least, that it is unconditionally consistent, sufficiently complete, beneficially fertile and gratifyingly elegant.

First and foremost, then, as we have been arguing consistently and repetitively always and everywhere and as we have steered our ship in the foregoing paragraphs, theories ought to exhibit these four characteristics:

1. consistency (absolutely and without exception);

2. completeness (to the fullest degree feasible);

3. productivity (towards growth);

4. elegance (for purely aesthetic reasons away from messy and distasteful obsessions).

These four features are also the criteria with which we evaluate abstract and structural theories regardless of the way someone is going to apply or not to apply theory to practice. The first attribute of consistency is essential, indispensable, sine qua non; upon the least sign of inconsistency, the theory must either be fixed or abandoned; the second attribute of completeness is a desirable feature of a "good" theory and is pursued to the fullest degree feasible: the more complete, the better: the third and fourth virtues of productivity and elegance are matters of systemic and aesthetic choice, so that a theory does not hit the wall and end abruptly after a few theorems, and so that it does not become cumbersome and, say, either monstrously repetitive and unwieldy or repulsively lame.

So, again, how can we evaluate the theoretical system of logic per $s e$ ? Not by world-observations (of course), but by checking our theory for:

1. breaches in its consistency;

2. holes in its completeness; 
3. dead-ends in its productivity;

4. impurities in its elegance.

In other words, we should not expect theory to tell us what it "means" by "truth"; it is an abstract conception and means nothing whatsoever. It is not theory's job to "mean"; it is our own call to check whether what we mean is represented fairly by the theoretical ambit that we are attempting to employ towards representing, organizing and reflecting the meaning that we are testing. So, regardless of whether "truth" stands for $i$. something that checks out or is "verified" by common accepted and ii. agreed consensus or something that is sincere, how do we proceed? One cannot miss that There is still another dimension to the concept: not one of quality and consistency but one of degree. So where do we stand and what do we appraise about the degree of certainty and relevance of these "truths"? Are commonly understood potential and necessary truths suitable interpretations for the truth and untruth values in a logical theory?

Potential truth is a mild flexible concept that is easy to reach and manage. However, if the best that checking and making sure can do is confirm that a premise "could be true" is hardly a fair target for rigorous thought, strict logic, argumentative philosophy and law, pure and applied mathematics and the sciences and even usual conversation on the level of everyday life. One needs ways towards more certainty from proofs than just confirming potentiality in a way-too-casual remark. No matter which shade of meaning we attach to "truth", we need our proofs to confirm that particular shade as secure; otherwise the price is vagueness and, alas, inbred fatal incompleteness.

However, there is a grave problem here: there is already a proved theorem in propositional logic stating:

$$
F \rightarrow T
$$

And, in view of the preceding paragraphs that would not "suggest" that a potential untruth potentially generates a potential truth; it should actually "conclude" that from a necessary untruth an essential truth could be inferred. And that is something intuitively suggesting that in our struggle to avoid vagueness and circumvent incompleteness we have steered our vessel into inconsistency and directed ourselves head on towards institutional non- 
sequitur. Because of that, necessary true cannot seem to be the case no matter how one strives to interpret it. Therefore, we are stuck regarding realworld applicability and relevance; our theory can include neither necessary nor potential intuitive truth of whatever sort.

There are two ways to fix this structural bug: to either correct or to replace the theory. We have shown how logical systems should be structured in relation to the world and we have also shown that current logic is flawed. At a later stage (another paper) we shall provide the new suggested classicaltype formal revised theory for logic that has been promised here. Hint: it is neither a three-truth-valued theory nor any other multi-truth-valued system, with infinite truth-values, indeterminacies and the like.

Theories vs theory. There exists a critical tension between the Greek word $\theta \varepsilon \omega \rho i \alpha$ (theōriā) and its Latin derivative loanword theoria coming with plural theoria. A marginal plural usage like the Latin one has at times been jumping back and forth even in Greek texts since a very long time ago. Literally, the word with a plural means viewings or overviews, therefore a more proper term in Greek would be $\theta \varepsilon \dot{\omega} \rho \eta \sigma l \varsigma$, theōrēsis, - a term having no unique English counterpart, being simply translated as "theory". This unfortunate situation leaves us with a term, theoria (Latin) or, equally, theory (English) meaning both $\theta \varepsilon \omega \rho i \alpha$ and $\theta \varepsilon \dot{\omega} \rho \eta \sigma \iota \varsigma$, i.e. truth and perspective. Indeed, a perspective can be related to reality; truth cannot.

When theories have the aim to be applied to the world, they may be called applicable, and when they are applied to the world, they may be called applied. An applied theory should not/cannot be any sort of world perceptions simply named "theory". By the way, spending billions for scientific equipment which supposedly bypasses our fraudulent senses just by recording data will be called "the recorder myth". The problem is not the clarity of the perception of the world; it is the fact that phenomena never appear together with their causes, we are the ones who hypothesise or select probable causes according to our needs. This has not stopped scientists adopting the "naïve recorder" myth: hypothesis non fingo, data colligo. Data themselves, collected through the unquestionable superiority of multibillion-dollar equipment, may be presented as ready-made theories. Scientists with machines, shamans with Holy Plants, all see parts of the we cannot see with our plain senses. But then again, why not, assuming 
everything we do perceive with our plain senses is also "theory"? Maybe we already assume that. No matter what the level of accessing reality is, what we see is relevant only to our neuroses and our need for psychotherapy; least of all, correlation cannot be celebrated as back-door-reintroduced causation.

Some more typical, yet odd (for western thought), characteristics of theōria $(\theta \varepsilon \omega \rho i \alpha)$ is that we may only have one theory in epistemme (as well as we may have only one epistēme, only one logic etc.) vs many theories in science, sciences, logics and philosophies; this happens since the theoretical context of those abstract concepts dictates that a plural number is meaningless. It is like saying: do you like musics? Music is an abstract concept and when referring to music in general we use the singular term. "Musics" (if such a term existed) would not refer to the concept of music but to the analytical series of different types of music. Another typical characteristic is that theōria is abstract and hence it cannot be verified or refuted by any kind of experiment. What can anyone evoke in order to refute number theory? Indeed, in the sciences it is commonplace to make measurements and call upon them as a basis of an attempt to adapt Euclidean geometry, even though it is an archetype which we may use whenever and if applicable; it is quite meaningless to refute it by "direct observable evidence".

When we say that through a point outside a straight line one parallel straight line can be drawn to it, then we have described Euclidean geometry as a subcase of a more general geometry where a different number of parallel straight lines can be drawn. Regarding the number of parallel lines that can be drawn, there are the following cases:

1. Zero parallel straight lines, i.e. we cannot draw any parallels. This is an apophatic, hence potentially meaningless direction: GaussRiemann geometry. Space etc. are curved: curved with respect to what? Gauss-Riemann geometry is insufficient as a stand-alone geometry. It is a geometry that suffers from the lack of the criterion of completeness.

2. Infinite parallel straight lines: Lobachevsky-Bolyai geometry. It is a chaotic geometry consisting of infinite cases. It is susceptible to an incumbent facet of indeterminacy. 
3. One parallel line: the only geometry that is both consistent and complete. This is why it is the simplest geometry.

Experience vs surveillance. Does experience (which stems from the reality of the world) not help in the formation of Epistemene? If it does, how could Science and Epistēmē be substantially different?

Observation of things existing outside and independently of our own observation leads to a book-keeping bank of a priori "first-hand" experience (empeiriā), in the sense that experience does not necessitate the existence of any theoretical prior. The focus here is on the agent/actor (not on the action). Abstract thought leads to a posteriori "surveillance", or overview (epopteiā), in the way that surveillance is based on prior theoretical treatment (and comes after experience). The focus in this case is in the action (not on the actor). In simple words, epopteia is the methodical approach and result and study of coupling an external and a priori abstract model onto a chosen set of empirical observations, and of using it as an interpretative tool or device or code towards studying the essence and behaviour of the entities or systems or processes under the particular empirical scientific observation, scrutiny and experimentation. Surveillance also implies general overview and general expertise. Is this not then what science does? Not at all. It is crucial to understand that while experience is a source of inspiration, so to speak, at the level of surveillance, we fully and totally cut ourselves off from any a priori reference to experience.

Mechanistically speaking, sensing is prior to any process; the very act of stimulating sensory organs belongs to the world and is not an inner process at all. Even the inner stimulation of the peripheral nervous system may be said to belong to the world and not to the thought-producing parts of our brain. However, mere stimulation is as effective for the acquisition of knowledge as it would be to stimulate a corpse. Cognitive science describes very well how all kinds of stimuli are turned into knowledge; Epistemology explains how we turn this knowledge into science (or epistēmē) and not into something else, say, witchcraft.

Experience is something from which one collects data about scientia, while the same data in epistēmē serve only as a reference frame or point, at best a starting one. From then on, science transforms this sensory 
input of observation into fields of study, in which it determines and defines the behaviour of the phenomena and returns this/the data as regulatory constitution, completing a vicious circle. First of all, epistēmē dissociates and distances itself from all this data collection, whereupon it backstages or stores them in boxes and "forgets" them as particular materially manifest entities, having set up on them an abstract archetype. It then assigns the phenomena back to the archetype much like the way we fit feet to shoes: given the specific instance and task, the shoes are not "right" or "wrong" in themselves; we just select the shoe that fits our needs and drop the one that does not, following tests of fitting, using, extrapolating. This is what abstraction means: to strip words of their meaning (to ascend to wider and wider supersets by removing specific characteristics).

Abstraction and/vs substraction. Among other things, Latin scholars must have realized that while the Greeks (always meaning Golden Era Athenians) used only one word for abstraction (due to their language and the use of theōriā), for Latin there had to be two words, abstraction and subtraction. Who was right and who was wrong? Did the Greeks miss one term or did the Romans use a redundant term but the structure of their language/thinking did not allow them to see through that?

Indeed, there is a conscious deliberate effort inbred in classical Attic to achieve precision in speech by matching concepts to terms (/ words) on a 1-1 basis: no less (semantic ambiguity and imprecision) and no more (semantic redundancy and wordiness). This ideal has been adopted and imported into classical Latin consciously. Whenever a violation of that choice principle appears to be violated, either in the original terminology or in its translations, an alarm has gone off for Lekkas, who looks for extra analysis seeking or demanding explanations. In this spirit he has often asked audiences why such a precise language as classical Attic Greek uses the same word aphaeresis, ג̇ should we say, using the term subtraction for the concept of abstraction.

This question belongs to the general discussion about the breach of calque on the part of Latin Scholars. Is it OK? If indeed the Romans were conscious of The Greeks heavily investing on keeping a 1-1 correspondence between meanings and words, which they were, this situation at hand borders on irregularity. In the normal context it is not expected on their part 
to either change a label or to merge two labels into one - and one cannot say "no big deal! It's just labels!". Humanity has paid such "innocent ambiguities" with tons of blood and tears. It makes a very big difference indeed to be able to distinguish between terms and it is not at all a "mental self-indulgence" or "autopathy" as many would eagerly call this attachment to accuracy. So, what is abstraction?

Let us take a specific idea, that of classifying up and down the species of kangaroos. I see a certain individual kangaroo grazing in the back yard. This is a tangible individual creature, a legitimate candidate for an element or member of sets. If I classify it together with all other kangaroos, I shall have included it in a set of creatures. I shall have gone up a level of abstraction, by including my grazing kangaroo with many others in set by using some categorical criterion. In so doing, though, I have subtracted or knocked off every specific feature of my individual starting kangaroo (e.g. it does not matter if it was male or female), keeping only a selection of common features as relevant; and these common features are a selection from the sum total of the individual features of my starting specimen.

So, what have I done? I have gone up some steps on the ladder of abstraction by successively subtracting and throwing out whole slices of the epistêton (semantic content, knowable information material) of my starting kangaroo's specific kangaroo characteristics, in order to form an including class that has fewer qualifying characteristics. So then, in repeatedly applying this procedure and subtracting and rejecting successive slices of epistêton, I ascend ever higher and ever widening successive steps to the supersets of marsupials, then of mammals, then of animals, then of living organisms, then of organisms of any kind (e.g. viruses are not considered to be "alive"), the system... At the end of this procedure there is finally the concept of one. "One" lies in the level of absolute abstraction: no meaning of the world is left - and this is a decision, not something I am going to observe anywhere in the world. Absolute total abstraction has been reached, there is no slice of semantic content left, all has been subtracted, there is none left, except the idea; just like the Cheshire cat in Lewis Carroll's Alice in Wonderland. Abstraction and subtraction reflect the same essential process.

All data and observations that guide the theoretical intuition and set it up as an abstract axiomatic model are merely a historical anecdote. For 
example, nobody is interested if the shape of the elliptical orbit of the planets was once inspired by an ancient conic section; on the contrary, science's industriousness is exhausted exactly in this process conveying back and forth observed properties of cones to orbits. One step further and scientists debate about the quantum fuzziness and the phenomenology of sections and orbits. In epistême , the phenomena are assigned back to the theoretical model which now constitutes the abstract space of surveillance. Abstraction has no further meaning from the world, nor can it have.

Cause-effect vs stimulus-stimulus. Another far-reaching implication of the difference between science and epistemēe is the very notion of causality. Causality for empiricism has been sufficiently described by David Hume - no need to repeat his famous example with the billiard balls. He himself is very sceptical about reducing expectations to causality. It is what we should call a stimulus-stimulus response and it concerns all similar empirical accounts of "causality". A stimulus in the environment is followed by another stimulus which we, under certain circumstances, may think of as falling under a causal relationship. The circumstances concern distance, both spatial and temporal, between the two stimuli. But the circumstances are accidental; humans in different conditions (age, alertness, health, expectations, prior knowledge etc.), or different animal and insect species may or may not perceive a causal relationship between two stimuli. Stimulus-stimulus relationship is an instinctive process that we may improve using e.g. our cognitive resources, but it will never be conceived as purely causal.

A causal relationship is purely conceptual outside the realm of reality; it shall never be dictated by reality, even in the simplest cases, but it is always meaningful within the propositional system one uses it. Let us consider a simple example: "my car crashes after sliding on a slippery road". The stimulus-stimulus relationship is this: "car sliding on the road", "car colliding on the barriers". Or this: "car tires touch the ice at a specific speed and wheel angle", "car tires slide" etc.

The causes of the crash may be all of the following (and we have to select according to the propositional system that we are using to examine the event): 
- The friction coefficient of ice.

- Me not paying attention.

- My wife who irritated me.

- My poor driving skills.

- The temperature.

- Wrong type of tires.

- The State that had not added salt to the road.

- A stroke that I may have had while driving.

- An intrusive wasp that might have stung me.

- A sudden ultra-high pitched loud noise that had distracted my concentration.

- Bad Karma?

Etc.

Apparently, the cause for me, for my insurance agent and for my yoga teacher will be very different things.

Conventions vs observations. Conventions are the backbone of epistēmé, since we define everything based on conventions and never based on observations (even if the nature of the phenomenon sometimes "dictates" what kinds of conventions may be more systematically productive). Conventions are mutual agreements that become absolutely binding until we decide to drop them or replace them. They are treated as "real" for as long as they are kept. They are agreements which we freely consent to, stating that we have agreed to... have agreed.

The important lesson from conventions is that pretty much everything may appear or may be treatable as relative and hypothetical and elusive until we make a convention; conventions here may be needed to address issues in mutual agreement regarding interpretation, conformity or mutual accord.

When we reach such a common agreement, consent so to speak, then, we are fully bound by it and the convention is treated as if it were a reality (there's the much sought-after reality!). The convention is valid until we decide to change it, again, after common agreement. The technical problems of conventions (how many people should agree? how universal is it?) are of paramount importance and even have ethical consequences 
(related to the type of consent on behalf of the community). However, conventions are not a luxury we may or may not afford; they are a necessity stemming out of the impossibility to bypass the fraud of the senses and to directly "see" the causes. "Truth", in its classical conception, is beyond reality and it is about the true being. The various causes we identify in this world are merely shadows of that true being and they are just some particular occasions of it.

Working Hypotheses vs experiments. How do we start our wellstructured, logical conceptualisation? Enter the Null Hypotheses $H_{0}$. The counterpart in mathematics are called axioms and they are completely abstract. Either way, in mathematics or in epistēmē, we are obliged to follow the directionality from the abstract to the concrete. While the sciences prefer working hypotheses to be dictated by data, in epistēmē and in mathematics hypotheses are abstract conceptualisations based on nothing really (while occasionally one could be inspired by historic or observatory inputs) - hence the "Null" part. Working (or Null) Hypotheses are sanctified in episteme only by their interpretative power as in Occam's razor: how many observations / outputs one such hypothesis can interpret in the simplest way possible and with the fewest exceptions. If another $H_{0}$ is not a "better" one (evaluated by the criteria just mentioned), it gets rejected, otherwise it prevails. In the sciences it is believed that $H_{0}$ 's must be derived from observation and tested view (since any $H_{0}$ must be testable and tests will decide its fate). In epistēmē, taking as a starting point observations or experiments is just an option, not an obligation.

When we finally reach the end, we then may deploy the analyticsynthetic method and the abstract-structural method. And again, in mathematics, as long as our starting point is abstract meaningless succession of terms and relations (meaningless as in devoid of a priori significance), we call this "the axiomatic method", whereas in the sciences it is considered proper and standard to document $H_{0}{ }^{\circ}$ s by means of data; this latter scientific process may be the cause of errors, or biases (cognitive, logical, and the like) exactly because we are attempting to connect theory and practice from the wrong end. 
Methodology of science vs methodology of epistēmē. Do all these results in a different methodology, or is epistēme just science called with another name?

As it may be emerging after all this preceding approach, the chief and critical difference between science and epistēme is the sense in the directionality between observed realities and mental conceptual models: science tries to "ascend" from concrete objects and phenomena (observation $\rightarrow$ experience, empiricism) towards abstract models, whereas epistēmē tries to "descend" from abstract models (interpretation, application $\rightarrow$ overview, surveillance) to reality. This is no news really; it is common knowledge and elementary textbook material that the pinnacle of science is the experimental method, invested heavily in sensory intake of real-world situations or in set up procedures, with a definite profile akin to statistics, as the objects observed are typically multiple, as in multi-member, multi-valued and multivariable.

The obvious problem, established by relevant theorems in the deductive Logic level-0 presently holding, i.e. current Statement Calculus (also coming under other equivalent labels), with its standard "if... then..." arrows, is that it is forbidden to deduce cause from effect, unless an instance of logical equivalence has been established beyond doubt or dispute, as in "if... then... and conversely", or "of and only if"; in case there is any bug in clarity here, it should suffice to take a look at an example of typical realworld situations in the section immediately preceding, laying out a horizon of alternative likely causes, which is not even close to being established as relatively exhaustive; and the scientific ambiguity shall remain fully fledged for as long as it will be even left imperfectly and shakily confirmed if the list of "likely causes" proposed or considered even exhaustive. These differences between the two outlooks are usually ignored, so that we often see one wearing the other's costume and impersonating the other in inconspicuous cross-masquerades.

More simply stated, unless a 1-1 correspondence is established, the direction of causality is always from the cause to the effect. Having as a starting point an effect, a phenomenon, and inferring the cause from that is logically inconsequent and trashy. Actually, it is the very formal logical fallacy of affirming the consequent: "if it rains there are clouds - there are 
clouds therefore it rains", which is not always true and the truth of the first sentence cannot be transferred to the second one. So, how can anyone theorize securely - and not just potentially - based on observations? How can one form theories, models, causalities based on effects, phenomena and observations?

Returning to actual practice, it is difficult not reach a highly inconvenient sad remark: because of all this, an attempted theory in science typically must be tested again and again (and again), against varied controlled and recorded and appraised environments, before it is verified the only difference with logical positivism is that now we verify theories with a field of mathematics that has no proving capacity: statistics. We are in the era of statistical positivism. The king is dead, long live the king!

Of course, the methodologies of both science and epistemene, on the level of collecting evidence and organizing it, are directly related to set theory; except that it is very easy to see and handle this fact in episteme e than in science; a good initial demonstration of this fact is evident in the discussion about the way in which the ancient Greeks coined and understood abstraction, discussed in the previous section. In the epistemonic overview and method, the direct connection to set theory is clear as daylight as opposed to what the sciences feel that they are doing, where a "property" is typically viewed and described as some sort of "content", which it isn't, as opposed to a criterion of inclusion, which is what it actually is. Both methods of science and epistemene rely heavily on the dual pair of pillars of the twofold pair of the analytic method (analysis-synthesis) and the abstractive method (abstraction-structure). However, only a mathematical theoretical approach gives this association focus and makes its constitution clear. A starting point in pure theory facilitates, disambiguates and necessitates the multi-level breakup and restitution of the entity under investigation. All this has been made extremely clear and stated in this particular manner by Lekkas for the first time in his texts for a college course textbook that he has coordinated (Lekkas et al., 2003) and re-recorded more compactly and independently in E M L (Papageorgiou \& Lekkas, 2018).

The key feature here regarding the entire conception is triggered by posing the fundamental question of where the boundary lies between the 
analytic and the abstractive method: where one ends and the other one takes over and how and, especially, why. This mess only gets resolved and proceeds onward with the realization and declaration of a "breakup and assemblage" or "scattering and gathering" and creation and recombination going up and down in elements (members) or in categories (sets).

This double method is done by creating supersets (abstraction) and subsets (structure) and then, if an element is selected, by analysing the element into various components and synthesizing the various components to create something else (or resynthesizing the initial element which, now, is not the initial element per se but a complete re-composure!). From these it is obvious that set theory should be able to describe in sufficient detail the difference between an element and a unit-set - something it does not do on an axiomatic level.

Since the method of epistēme has been presented elsewhere in much more detail than it is possible to do here, we shall restrict our presentation to a simple example: that of apples:

- Analytic method.

- Analysis: breaking down a specific apple into carbohydrates, vitamins, proteins, fat, water or stem, peel, seed etc.

- Synthesis: taking the simplest ingredients which (by convention), which we have identified in analysis and compose any food really out of them.

○ (Re-synthesis, Gr: "anasynthesis": re-composing the same element, an apple, out of its analytic segments).

- Abstractive method.

- Abstraction: taking out semantic content from the unit-set [apple]. The process would result is something like this: apple $\rightarrow$ fruit $\rightarrow$ foodstuff $\rightarrow \ldots \rightarrow$. Or apple $\rightarrow$ tree $\rightarrow$ plant $\rightarrow$ living organism $\rightarrow \ldots \rightarrow 1$. "One" is a void signifier.

- Structure: taking properties (crunchiness, redness, roundness etc.) and including them gradually into subsets until we have described all the properties that are present in an apple (always by convention) 
The implications of the distinction between these two pairwise methods are as far-reaching as anyone should be able to conceive. Drifting back and forth from sets to elements (or from singletons to elements, or from analytic to abstract components) and from elements to their constituent parts and back is a classic fallacy that science doesn't even recognize as such (exemplified in some extreme cases where people compulsively tossing and discussing theories and concepts do not even realize where and when and how many times they keep losing it conceptually and/or perceptually and how badly, as in the case of inextricably confusing continuum vs discretum in e.g. quantum mechanics).

Physics vs mathematics. This is not just another reason why there is a dichotomy between science and epistēmē. Physics could, should have been representing epistemen. The matter of the fact is that physics is a domain that is typically caught as countering mathematical principle and, hence, coming out as non-epistemonic.

Why so? Any physics textbook is full of mathematics! Mathematics is said to be the "language" of physics! Is it?

Mathematics can be used as:

1. language / metalanguage,

2. methodology,

3. interpretative system,

being within itself neither of the three; just like a tomato is not in itself naturally meant as "food". Something is not defined by its use: a mother is not a washing machine because she washes her children's clothes. One may also point to two serious problems: the problem of logical causality and the problem of "mathematical utilitarianism".

Mathematical utilitarianism may be viewed as the case of using two modern washing machines to support a washbowl. It is when mathematics just serves for decorative purposes with the sole aim being to support a physical "theory". Mathematics is used ad hoc, with disrespect for its own limitations and its own methodology. In a direct or indirect effort this practice muddies the waters making, along the way, the two mathematical fallacies Lekkas has introduced as a complementary pair: i.e. quasimathematicity and mathematicism. The former means to dress up even false 
theories in equations so they deceive about their validity (quidquid mathematica dictum sit, altum videtur), and the latter is tantamount to using more complicated mathematics than necessary to deceive people about their importance.

If science is a way to record observations systematically and to develop attempted theories based on these observatory data, epistēmē is a knowledge system logically structured. Basically, science is what physics does whereas epistème is what mathematics does.

For physics, it is acceptable to define force as the cause of acceleration. Now, may that be the cause? Hypotheses non fingo, it could well be God Shiva. Physics defines its fundamental terms based on effects an elementary logical error. The second derivative of speed, acceleration, is an effect of an effect. By its definition, acceleration is an indirectly indirect effect of an effect of some observed feature of motion; in more mundane terms, acceleration is a rate of change of velocity which in its turn is a rate of change of position. How on earth an observational empirical science ties it to mass, calls their product a force, then claims force as an "extant", "direct" underlying entity and upgrades effect of effect times a scalar coefficient to stating it as a "cause", is something that totally beats our own sense of logic. Exactly because it has defined force this way and not in principle, physics misses that both uniform circular motion and the simple harmonic oscillation are very nicely definable as inertial movements, not as accelerating ones; and, what's worse, it misses the opportunity to understand the real grade of complex analysis and clean up the mess in the duality of matter vs energy and the structural fabric of space-time.

Science and witchcraft. Feyerabend questioned the superiority of science against other knowledge systems. However, we argue that he did not go far enough. Witchcraft (or magick or sorcery or shamanism etc.) may be said to be any tradition, or process, that focuses on the utilization of spiritual, or supernatural, powers, entities and related effects. To that extent, both science and epistèmē leave plenty of room for spiritual entities, but with a crucial difference: on one hand, scientists rend their garments denouncing witchcraft in full rage, but, nevertheless, leave a back door open for any kind of entity to not only enter, but become a constitutional element of science (e.g. the definition of force in physics). On the other hand, epistemene is 
completely neutral on the subject since it is based on the logical structuring of knowledge, no matter how this knowledge was gained. It could not have been any different for epistēme : since its basic tenet is that we may never know the world directly due to the fraud of the senses, it would be absurd to argue, on the same page, how the "real world" is and how it is not. That is reflected in the way episteme $\bar{e}$ handles causation since it does not refer to any "objective" or "material" cause that has been observed, but rather, sets causes a posteriori based on surveillance.

Does science invoke causes through the repetition of effects (e.g. experiments), much like shamans do? Then, the most consistent assumption is that science is theoretical witchcraft; this is consistent with the sense in the directionality between cause and effect. Going from effects to causes or from causes to effects (when no 1-1 relationship has been established) are two completely different paths - at least as different as science and epistēmē are to each other.

Reason vs rationalism. The type of logic used within an epistemonic context will be presented in later articles. Suffice to say here that linguistic vehicles must be able to distinguish partial contradictions and contradictions. Again, Latin did not help by dropping one of the two negation particles of Greek. The two negation particles are essentially instrumental towards expressing the minimum logical quadripolar relationship between two structurally elementary one-verb clauses, especially those connected subordinately; in ancient or more synthetic languages the second clause may well be an infinitive, or participle or gerund. This is exemplified by the formulation:
1. $p: q$
2. $\neg p: q$
3. $p: \neg q$
4. $\neg p: \neg q$

These four instances do not "inevitably" identify pairwise; for example, it is not necessary that (2) and (3) state the same thing or, much worse, that (1) and (4) are identifiable. 
An example:

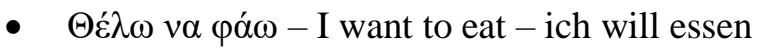

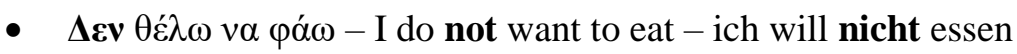

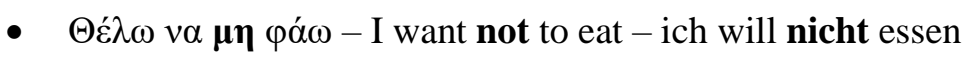

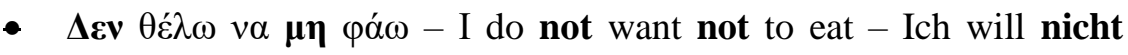
nicht essen (= Ich will essen!!)

Double negation is substantially crashed in German, (not cancelled), and resembles a matter of circumstantial (non-essential) context in English while in Greek the two separate negations make for a totally different statement between judgment and potentiality.

But it would be a simplistic quick verdict to say that the problems in logic are only language-bound. There is a conceptual framework that should be addressed as well.

\section{THE WHY'S OF LOGIC}

We live in the era of specialization. We consider specialized individuals as necessary and beneficial for science and more specialized individuals as even more necessary and even more beneficial. Both a surgeon specialized in knee surgery and a physicist specialized in black holes are paid more money than general surgeons and "unspecialized" physicists. Deepening knowledge (approfondition, $\varepsilon \mu \beta \dot{\alpha} \theta v v \sigma \iota \varsigma$ ), an opposite trend to widening, is appreciated more in an era favouring specialization at the expense of generalization. If this trend continues, as a society we should be prepared to distribute an immense amount of wealth to individuals who know increasingly more for narrower and narrower knowledge domains and, in the end, to ultimate specialists; and, as an old joke has it, those will be individuals who know everything about nothing.

Epistēme started from the need of reaching conclusions despite the fraud of the senses, and not based on the fraud of the senses as is the everimminent case in science. Concentrating on the specific and not on the general overview leads to false conclusions. For example, one can turn towards the simple arts (for an extensive presentation regarding theory of arts: Lekkas, 2018). What starting point should one occupy in order to seek 
utility in painting, discuss about the work of art in dance and talk about performers in sculpture? Painting has no utility, dance has no concrete material body as work of art to show for itself and in sculpting there is no performer. When attempting to categorise the six elementary arts we see that there are arts without a concrete material work of art (music, dance), without a performer (sculpture, painting), without special raw material (dancing, poetry) and there is one art which has a concrete product with practical utility (architecture). How can anyone miss general overview of arts and draw conclusions for any of them having as a reference point any one simple art?

But let us explore some examples from more formal knowledge domains. We can hear a spectrum of sound frequencies almost ten octaves wide. However, when it comes to visible light, the frequencies we are able to see hardly span one octave. How can we transform visible phenomena into sounds and vice versa, as is the trend in popular astronomy nowadays? Or in mathematics, how is anyone going to conclude about which type of geometry is more fundamental? Could someone be concluding that nonEuclidian geometries are more fundamental while describing them using Euclidean terms? Or, maybe, by deducting the Euclidean postulate of parallels (only one parallel) from non-Euclidean geometries which either accept zero parallels or infinite parallels? It is only apparent that our methods for reaching conclusions in science are at best lacking basic elements.

When observing effects, what is the observer allowed to infer? Save for the unique case of 1-1 correspondence (“iff" in logic), no function exists, just an image, and it is impossible to reach conclusions. It is this basic logical principle that science continuously overrides.

Whether one takes science, witchcraft or epistèmē as a starting point, one observes phenomena in the world (effects). In witchcraft-like approaches, it is from these effects that individuals infer the causes (begging the question). Then they attempt to evoke the causes by recreating the effects. In witchcraft, at least in its folkloric version, people see some kind of disaster and feel bad about it. Then, they infer that some entity did it. Then, some people try to invoke the entity by recreating disasters (e.g. sacrifices) in a ritualistic way. In science, equally, scientists spend billions to recreate 
phenomena and verify (invoke?) the hypothesized theories, when theories cannot ever be verified or falsified in "real reality". In this sense, traditions, such as shamanism, it only figures that certain classes of people argue that they are much more environmentally friendly when instead of particle accelerators they use Peyote. Usually, individuals see/verify what they wanted to see in the first place. The difference is that in science the selffulfilling prophecy is driven by our conscious will, but crumbles in variety if it cannot be turned into a modelled statistic, whereas in shamanism the selffulfilling prophecy is attributed as driven by our unconscious symbolic mind: in the latter case, the process is at least psychotherapeutic.

The Greeks knew that theory is beyond experience. At some point they understood that using theorems upon theorems to prove that assumption, it would result in either a circular argument or in an argumentum ad infinitum. Understanding that both ways are problematic and that one could never verify any theoretical assumption based on observations, Euclid invented axioms. Axioms have nothing to do with experience but are completely bound on mutual agreement; when, if and as long as individuals agree. Others are free to propose their own axioms and see how the theoretical system develops in alternative ways. Axioms are simple, general and elegant. But another thing is much more crucial for everyone to realize: axioms are totally and absolutely abstract statements; as such, they have had the sum total of their semantic content subtracted from them; therefore, they are phrases that mean nothing whatsoever: they are void signifiers, elected and tested perchance as schematic interpretation frameworks towards testing and organizing behaviours of applied complicated theoretical constructs. That is where the virtues of mathematical theories come from, as laid out in our section "Reality vs truth" above.

Is logic nowadays simple, general and elegant? Or is it divided into many sub-disciplines with various axioms, assumptions and goals? Should we develop theoretical systems in order to serve some goals? Of course not. Why do we develop theories? Here, another confusion lurks. What is meant by "why"?

In Classic Antiquity there were three types of causes: the poetic, the telic and the necessary ones. From these three, only the necessary cause is used in theories. The poetic cause is about who said or did it. So, the 
conclusion "this type of logic is valid because 'many people believe it/have developed it' or because 'an important mathematician proposed it" cannot apply (since it addresses the poetic cause). Equally, the conclusion "this type of logic is valid because it works well in this application" cannot apply (since it addresses the telic cause). We cannot have a general logic based on authority or utility. We cannot accept an ant reaching conclusions about the world having as a reference point its anthill or its own utility!

The necessary cause is the only sound answer to our "why's". It is based on the method of epistēme for developing theories (the analyticsynthetic and the abstract-structural dual, pairwise method), evaluated only by the four said criteria of consistency, completeness, theoretical productivity and elegance. All these do not constitute formal logic; however, they are the inescapable foundation for the formation of such a kind of logic. But are we able to formulate such a logical system? And, if yes, what would it look like?

\section{DEVELOPING A SYSTEM FOR LOGIC}

The starting point are definitions. A definition is a freely chosen phrase commonly accepted by the speakers, valid and binding upon free choice until it is revised or repealed, again within common agreement, which describes a concept fully and exclusively. This was the definition of "definition". Without definitions we do not have a criterion of identity and otherness, total or partial. In other words: we don't know what we are saying and what is happening to us, a problem identified already by Plato.

Such rules for focusing on concepts determine when something is affirmative and when it is negative; when it coincides and when it is completely and/or partially different from something else. The Classical Greeks used to treat the regulating and the regulated differently. In everyday life we can make abstractions and archetypes based on observation, but then, at a next stage of applied perfectionist or simply artistic formalism. It is the typology of the regulate ( $\varepsilon \rho \rho v \theta \mu l \sigma \mu \varepsilon \dot{v o v})$, sometimes idealized, but certainly

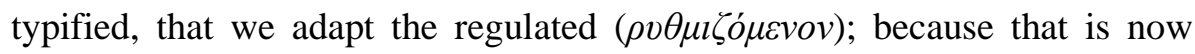
promoted to acting as the ideal prototype regulating norm ( $\rho v \theta \mu i \zeta o v)$ for the

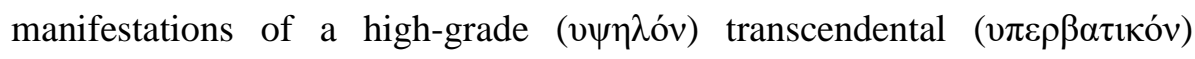




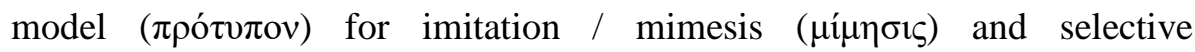
reproduction of exalted features.

Given due definitions; the rules of inference help us decide first of all (even informally) what will be considered as an individual or an element and what as a set of elements, and immediately afterwards what is mapped in what, what is the scope and the range of the definition; in other words, which are the archetypes and which are the images of these models in a paired correlation between two sets. The rules of inference should not overturn the direction of the mappings, should not attempt to alternate uncontrollably models and images or, in particular, causes and effects. They then agree on how to manage inclusion, participation (total and partial), correspondences or not of concepts and reasonings, affirmative and negative clauses.

After understanding the asymmetrical nature of affirmation and negation, only then may we move on to the five validly standard forms of the inference, which are affirmative and negative production (deductio), reduction (which basically is reductio ad absurdum) and the ascending or generalizing and descending or specializing induction (inductio). After all this what closely follows is the scientific method with its pillars, as we said, the two twin pairs of the analytic and abstractive method (analysis-synthesis and abstraction-structure), within full awareness of the limits and scope of the two, both internally and towards each other.

Consequently, it should be seen as essential: a) that it is necessary to know what each one phrase says and what it does not say, b) the "span" of each phrase, that is, where each one begins and ends, and where it does not begin and where it does not end. Then we look at what does not check out and we don't do it. For instance, we do not produce affirmative-negative symmetries. We do not stick in the analytic method where the abstract method is needed and vice versa, since these two approaches are mutually exclusive. We do not drive ourselves deductively from negative hypotheses or givens to affirmative conclusions, nor from affirmative hypotheses or givens to negative conclusions, leaving such treatments to be carried out reductively; special attention is required towards some crypto-negative concepts such as darkness, health and death. We do not form general conclusions through specialized reasoning or into specific conclusions through generalized reasoning. We do not confuse phases of the analytical 
method with phases of the abstract method. We do not apply the synthetic method before the analysis is exhausted, nor the structural method before the abstraction is exhausted, we do not mix them, we do not go backwards etc. Finally, in reductions, there is no need to prove anything or to develop methodical counterarguments or to develop proving methods. A single contradictory case or otherwise invalid point to identify, a counter-example, is enough to disprove the relevant part of a mathematical theory.

At this point, let us be aware that there is a very clear boundary between archetypal abstract theory and observational empiricism, that their directionalities are reciprocally reversed, that logic (as opposed to witchcraft) does not allow us to automatically draw working hypotheses from conclusions: such theorems do not exist and the reasons why they do not exist are clear. This also means that we can and should neither create mechanisms from samples and examples nor extract causes from any effects: one is obliged to either make theory, or observatory recordings, (ad hoc) groupings and statistics.

The persuasion of mature ancient thought was to primarily exhaust pure reason within its margins, to investigate phenomena and ideas first and foremost through it, to enter into the framework with which it provides us for the protection of ourselves and of others, for the sake and safeguard of equality, and only afterwards may we stretch the wings of our imagination, knowingly and consciously and not unconsciously and carelessly - as long as we do not begin to cancel it all dangerously at the level of public life and of objective discourse.

\section{CONCLUSION}

A total reform of the field called "science" is needed. As in any therapeutic treatment, the first step is to identify the problem. There are many levels in doing so, and one of the most prominent and handiest and securest ones is related to logic.

A sinister confusion always lurks in regard to what logic is and what it is not and what people mean when using the term. Is it common sense? No, mathematics has nothing to do with the senses; on the contrary, it is the abstract system that we will call into action so as to organize the sensory 
input, the observations, the data or whatever else coming from "reality", i.e. from "the world out there".

Compliance with Ethical Standards:

No funding received.

Ethical approval: This article does not contain any studies with human participants or animals performed by any of the authors.

\section{REFERENCES}

Lekkas, D. E. (2018). Fundamental isues in arts. In K. G. Papageorgiou (Ed.), Towards a structural theory of art (pp. 34-123). Athens: Dromon.

Lekkas, D. E. (2003). Arts II, volumes A to E and, handbook for the course, Programme of Studies in Greek Culture, School of Humanities. Patras: Hellenic Open University.

Papageorgiou, K. G., \& Lekkas, D. E. (2018). On the Methodology of the Analytic Method: Historical Account, Epistemological Suggestions, Stages. Epistēmēs Metron Logos, (1), 70-89. https://doi.org/https://doi.org/10.12681/eml.19244

Papageorgiou, K. G., \& Lekkas, D. E. (2020). Towards the model of contributory expert generalists. Arche, 17(33), 123-143. https://doi.org/https://doi.org/10.19090/arhe.2020.33.123-143

Papageorgiou, K. G., and Lekkas, D. E. (2019) 'The predicate fabric of abstraction: the hard test of logical inversion', Epistēmēs Metron Logos, (2), p. 69. doi: 10.12681/eml.20573.

Papageorgiou, K. G., and Lekkas, D. E. (2020) 'Verification in theory and in the sciences’, Epistēmēs Metron Logos, (3), p. 25. doi: 10.12681/eml.22106. 


\author{
KONSTANTINOS G. PAPAGEORGIU \\ Univerzitet u Atini, Odsek za filozofiju, Grčka \\ DIMITRIOS E. LEKAS
}

Helenski otvoreni univerzitet, Studije grčke civilizacije, Grčka

\title{
EPISTEMME VS NAUKA
}

Sažetak: Da li je „nauka“ pojam koji korespondira svom grčkom pretku, epistēmē? Tradicionalno, oni su mišljeni kao identični pojmovi. Oni to, međutim, na više načina nisu, i čitalac je pozvan da ih vrednuje ne na osnovu njihovog hronološkog reda, već na osnovu specifičnih sistemskih karakteristika koje su ovde prikazane. Biće prikazana i ključna razlika između epistemoničkog (od epistēmē) metoda i naučnog metoda. Jedna od glavnih razlika o kojoj će biti raspravljano tiče se logike, i to kako kao pojma, tako i kao teorije. Ono što autori ovde prikazuju ni u kom slučaju nije sinteza prošlih ideja; mi priznajemo da su se pojedine slične ideje možda pojavile u prošlosti, ali nikad u formi koja je prikazana ovde ili unutar sistema koji je predložen u tekstu koji sledi. Ovaj rad nije posvećen tome ko šta nije rekao povodom bilo čega što mi predlažemo ili ko je možda imao neke slične misli unutar nekog irelevantnog konteksta. Sve ideje ovde potiču iz izvornog rada koji smo sami ostvarili i sistem koji sledi jedinstven je, a što je od najveće važnosti, on istovremeno jeste spoljašnja kritika - jedina istinski spoljašnja kritika - institucije moderne nauke i ozbiljnih nedoslednosti koje „naučnici“ (iz bilo kog razloga) u njoj više ne mogu da uoče.

Ključne reči: naučni metod, epistemonički metod, teorijsko veštičarenje, logika

Primljeno: 23.2.2021. Prihvaćeno: 19.5.2021. 